\title{
The Analysis of the Housing Markets in Beijing and Washington, 2005-2014
}

\author{
Xintong Yao \\ Saint Mary's School, Raleigh, NC, USA \\ Email: gracie.yao16@gmail.com
}

Received 28 August 2015; accepted 27 October 2015; published 30 October 2015

Copyright (C) 2015 by author and Scientific Research Publishing Inc.

This work is licensed under the Creative Commons Attribution International License (CC BY). http://creativecommons.org/licenses/by/4.0/

c) (7) Open Access

\section{Abstract}

Since the economic reform of the late 1970s, China has achieved a magnificent economic growth. China's socialist market economy has become the world's second largest economy by nominal GDP, reaching 10,380 billion dollars and holding a 13.43 percent share of global GDP. The dramatic growth of economy also has boosted the development of Chinese housing market. But the question remains: Is the Chinese real estate market developing in a positive way? This paper first compares the housing prices in Washington and Beijing using hypothesis test for population means and linear regression model. It is found that despite China's low housing price in early years, the average housing prices are almost the same in Beijing and Washington area. The most reasonable proposal is that the personal income in Beijing is higher. However, the data and the line chart illustrate that the opposite is actually true. Therefore, in order to further explore the reasons behind the high housing prices in Beijing, the paper then statistically analyzes a series of factors, including per capita income, limited land resources, city functions, unbalanced regional development, the influence of cultural traditions, the government policies, the structure of housing supply, and the investment demand. The last part of the paper points out the problems of the Chinese housing market by looking at the housing price to income ratio and the economic growth trend. The result shows that Chinese housing price has far exceeded common people's affordability, which has the potential to cause social instability.

\section{Keywords}

Housing Markets, Beijing, Washington

\section{Introduction}

America and China are the world's largest and second largest economies respectively. America has been the 
greatest superpower for the past hundred years, with a 22.53 percent share of global GDP in nominal terms in 2014, whereas China is an emerging economy because of rapid growth and industrialization and has just embarked on the path of strength and prosperity [1].

China's incredible economic growth over the recent years has long been a hot topic. According to the histogram of the history of global GDP, China's GDP had dropped substantially throughout history (Figure 1). In 1820, the country's GDP accounted for almost 33 percent of the world's overall GDP. However, its share dwindled drastically in the 19th century, during which industrialization swept Europe and promoted the rise of America and many European countries. The 20th century was a period full of calamities to China—civil war, foreign invasion, and disastrous central planning, which thwarted it from experiencing industrialization and dragged its economy into the swamp. Thanks to Deng Xiaoping's economic reform in 1978, China has transformed from a central-orientated economy to the current market-oriented economy and has become one of the fastest-developing countries in the world. Even though the GDP of America is more than 7000 billion dollars than that of China, many economists have predicted that China's economy will overtake America's in less than two decades [3] [4].

The economic reforms also have generated a great influence on China's real estate market since the 1998 housing reform ended central-planning nature of Chinese real estate market and made housing purchase a means of investment to the Chinese people. According the data from the National Bureau of Statistics of China, China's real estate investment increased steadily from about 4\% of GDP in 1998 to about 15\% in 2013 [5]. It is clear that the housing market is playing an increasingly important role in China's economic development.

Washington and Beijing are the capitals and the political centers of the United States and China respectively. Comparing the maps of the two countries, we can find that not only the shapes and sizes of two countries similar, but also their capitals are approximately in same positions in terms of latitudes (Beijing is at $39^{\circ} 55^{\prime \prime} \mathrm{N}$ and

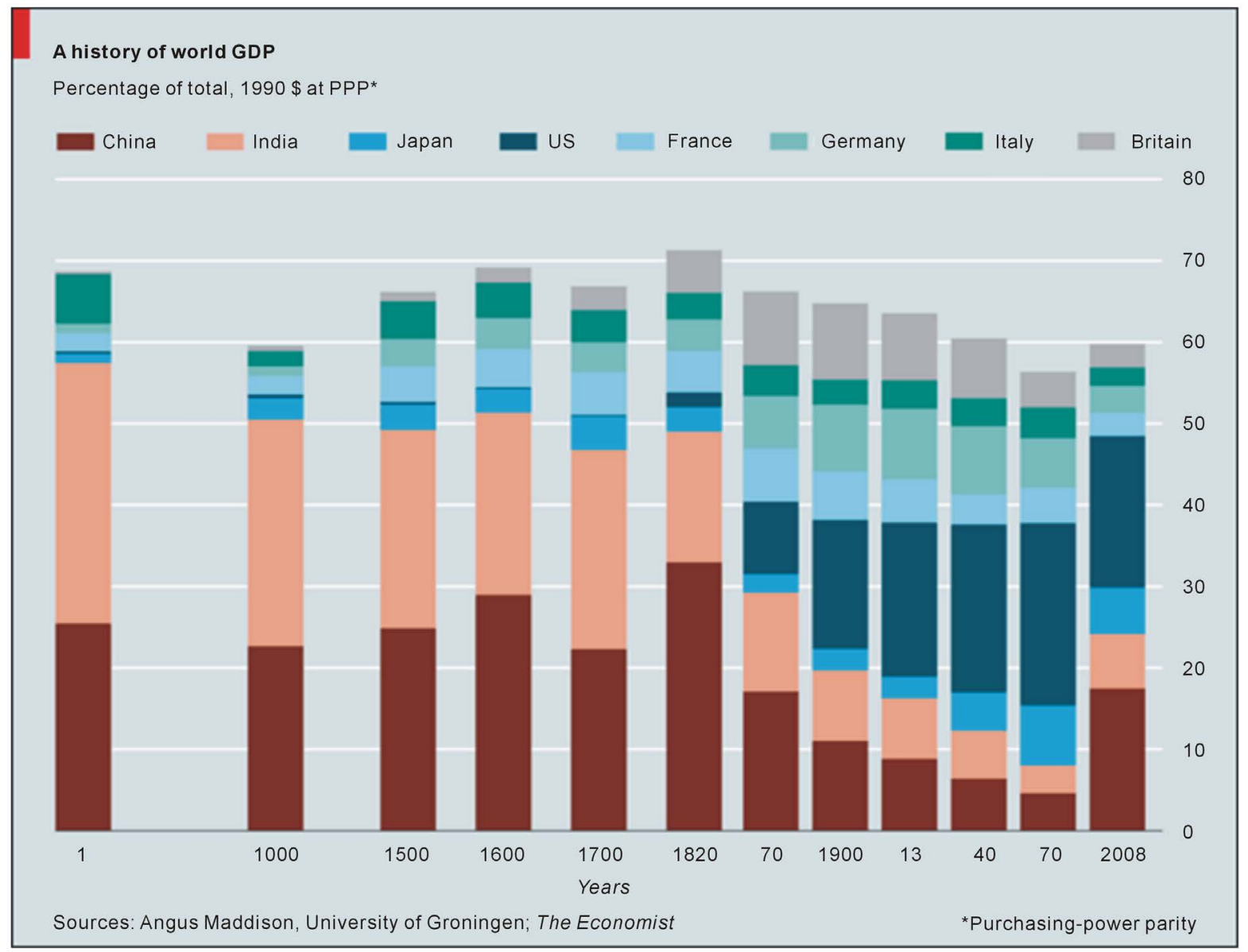

Figure 1. A history of World GDP [2]. 
Washington is at $38^{\circ} 90^{\prime} \mathrm{N}$ ) [6] [7]. Looking at the growth trend of housing prices, the per capita income, GDP, land resource, city functions, government's policies, and cultural issues of the two cities, we can find the reasons behind the high housing price in Beijing and explore the problem of Chinese housing market.

\section{Data Analysis and Results}

\subsection{The Comparison of Housing Prices in Washington and Beijing}

\section{Data Overview}

When we are gathering the data of housing prices of Washington D.C., one thing should be taken into consideration: most of the people who work in Washington are commuters from the surrounding Maryland, Virginia, and West Virginia. The 2014 estimated population of Washington is 7,061,530, but these commuters raise the city's population to more than one million during workweek [8]. Therefore, when analyzing the house prices, we need to also consider the housing prices of areas surrounding Washington (Figure 2).

Figure 3 shows the change trend of average housing prices of Washington and areas surrounding it from 2008 to 2014. There is still a slight decrease from 2008 to 2010, which is the lingering aftermath of the Global Financial Crisis. Also known as the financial crisis of 2008-09, it is considered to have been the worst financial crisis since the Great Depression. And the house market was one of many areas suffered. Starting from 2011, the house prices fluctuated, but the overall prices increased. The United States is gradually recovering from the economic crisis.

Figure 4 is the housing prices in Beijing from 2005 to 2014. Compared to that of Washington, the housing price in Beijing has increased dramatically, from $\$ 70.94$ per sqft in 2005 to $\$ 280.87$ per sqft in 2014 . The scatter plot shows a strong positive linear correlation between time and housing prices.

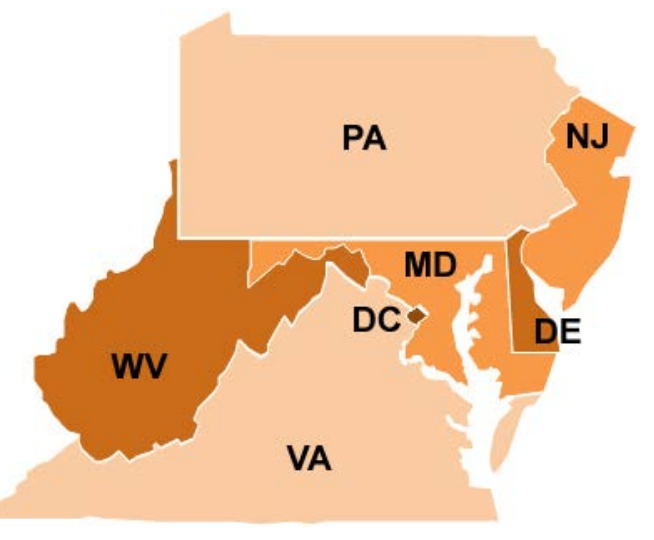

Figure 2. Washington and its surrounding states [9].

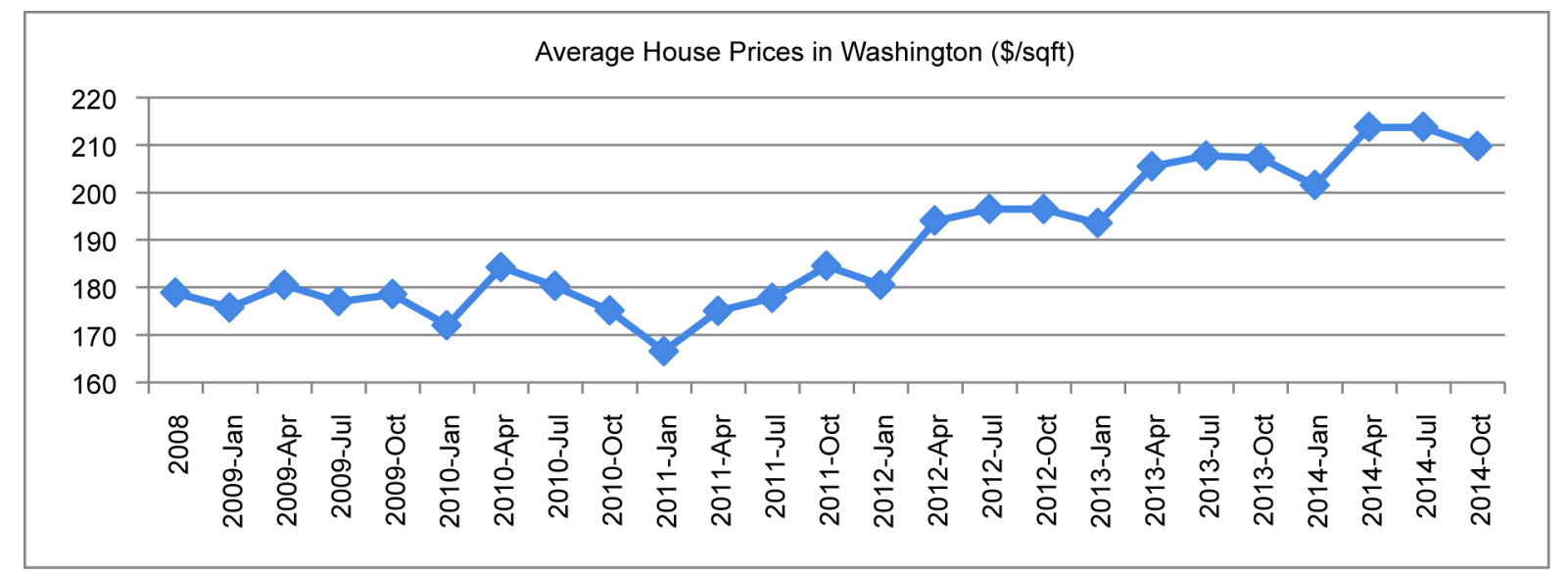

Figure 3. Housing prices in Washington from 2008 to 2014 [10]-[13]. 


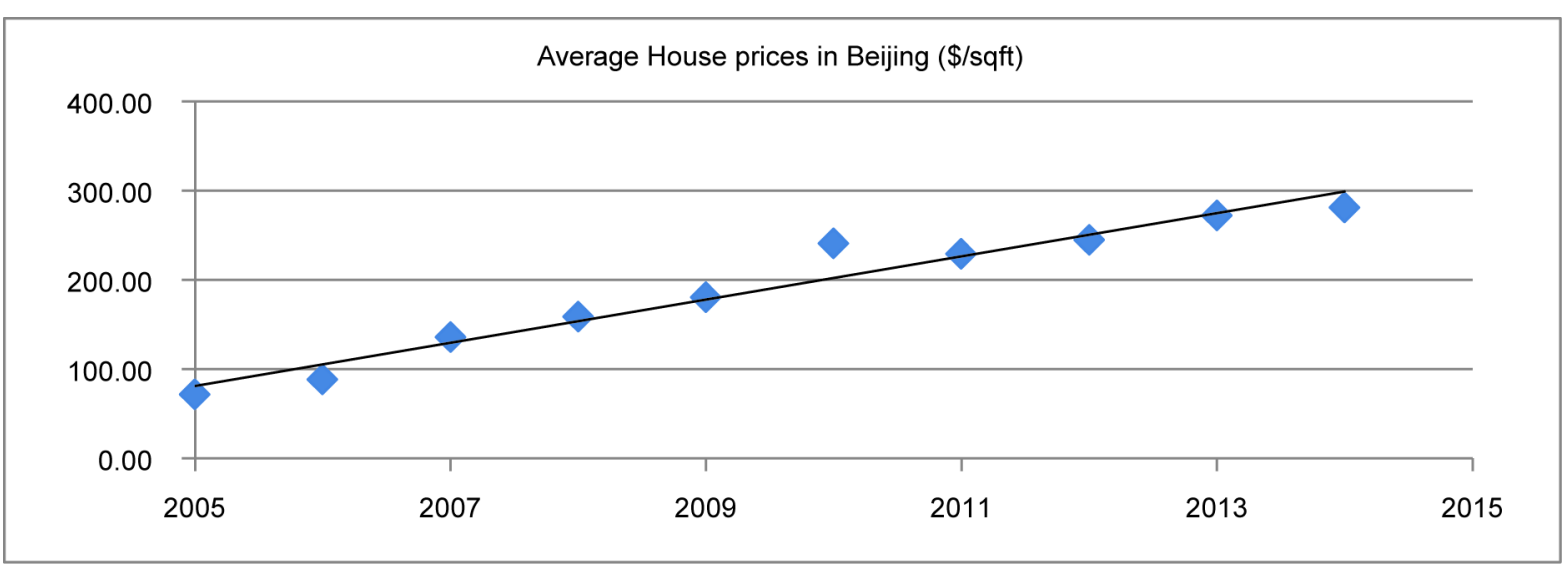

Figure 4. Housing prices in Beijing from 2005 to 2014 [5], $\hat{y}=56.7202+24.22398 x$.

\section{Method 1: Hypothesis Testing-Comparing Two Population Means}

A two-sample hypothesis $t$ test is carried out to determine if there is convincing evidence that from 2008 to 2014, the housing price in Beijing, on average, is higher than that in Washington. Let the significance level $\alpha=$ 0.05 .

Parameter: $\mu_{1}$ : the mean housing price in Beijing from 2008 to 2014.

$\mu_{2}$ : the mean housing price in Washington from 2008 to 2014.

Hypothesis: $H_{o}: \mu_{1} \leq \mu_{2}$.

$u_{a}: \mu_{1}>\mu_{2}$ (claim).

Critical value: Since the degree of freedom is defined as the smaller sample size minus 1 , which is 6 , and the alpha level is 0.05 , the critical value can be found using $t$-chart: $t=1.943$.

Standard test statistic:

$$
t=\frac{\left(\bar{x}_{1}-\bar{x}_{2}\right)-\left(\mu_{1}-\mu_{2}\right)}{\sqrt{\frac{s_{1}^{2}}{n_{1}}+\frac{s_{2}^{2}}{n_{2}}}}
$$

From the data, we can get the following results:

$\begin{array}{ll}\bar{x}_{1}=229.320 & \bar{x}_{2}=187.958 ; \\ S_{1}=45.324 & S_{2}=13.913 ; \\ n_{1}=7 & n_{2}=7 ; \\ \mathrm{df}=n_{1}-1=6 & \alpha=0.05 .\end{array}$

After the calculation, $t^{*}=2.308182$.

Decision: Since the test statistic is greater than the critical value, it falls under the rejection region. Therefore, the null hypothesis is rejected.

Conclusion: This test shows that there is sufficient evidence at the alpha level of 0.05 to claim that from 2008 to 2014, the mean housing prices in Beijing is higher than that in Washington.

\section{Data Overview}

As can be seen from the data (Figure 5, Table 1), the housing prices in Washington area is relatively stable, with a range of $\$ 33.75$ per sqft and a standard deviation of $\$ 75.085$ per sqft, whereas the range of house prices in Beijing is \$209.927 per sqft and the standard deviation of \$13.91 per sqft. In 2005, the house price in Beijing was really low, but since 2009, it has rapidly surpassed that of Washington, and the difference between their housing prices seems to continue growing. The growth rate also shows that the housing price in Beijing has increased more dramatically than in Washington, which an idea that will be proved statistically using the linear regression model.

Method 2: Linear regression model comparing the linear trends

In order to compare the growth of the housing prices in two areas, a linear regression model needs to be found. 


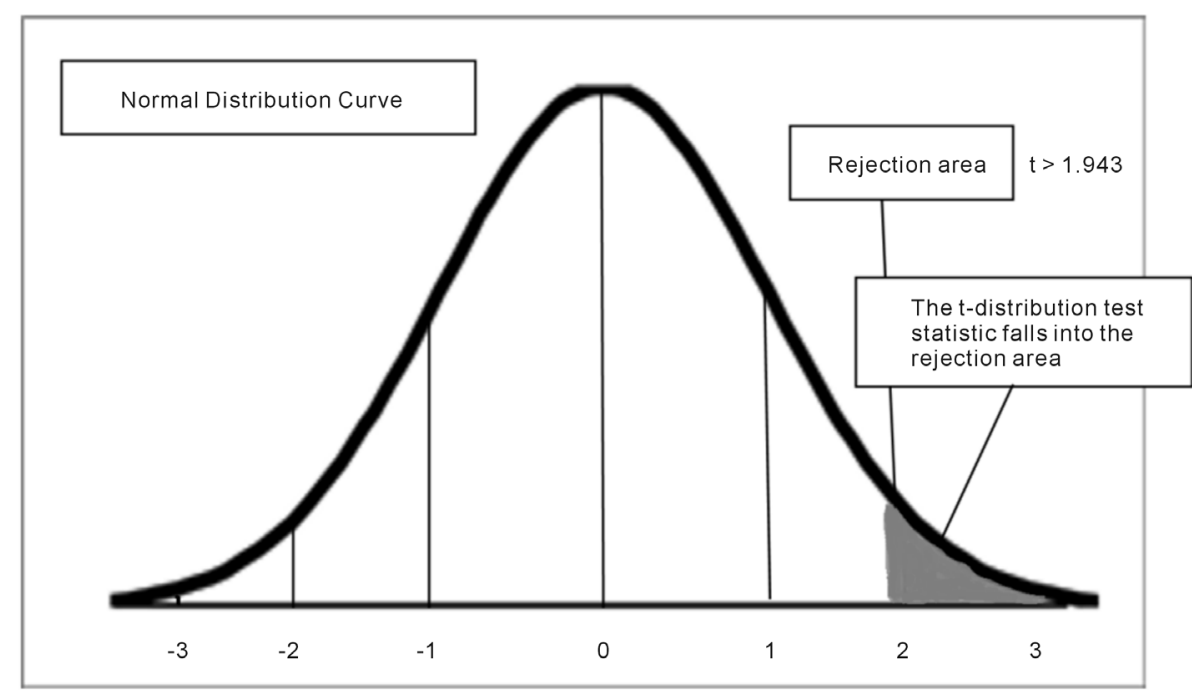

Figure 5. Normal distribution curve.

Table 1. Housing prices in Washington and Beijing [5] [10]-[13].

\begin{tabular}{ccc}
\hline Year & Average House Price in Washington $(\$ / s q f t)$ & Average House Price in Beijing $(\$ / s q f t)$ \\
\hline 2005 & & 70.938 \\
2006 & & 87.748 \\
2007 & 178.83 & 135.594 \\
2008 & 178.1875 & 158.332 \\
2009 & 177.5625 & 179.922 \\
2010 & 175.9375 & 240.594 \\
2011 & 192 & 228.803 \\
2012 & 203.5 & 244.67 \\
2013 & 209.6875 & 272.055 \\
2014 & 33.75 & 280.865 \\
Range & 13.91285133 & 209.927 \\
SD & 187.9578571 & 75.08465988 \\
Mean & & 189.9521 \\
\hline
\end{tabular}

In the following calculation, we use 1 to 10 to represent 2005 to 2014, which is the explanatory variable, so that the slope is easier to compare.

Beijing:

$\Sigma x=55$

$\Sigma y=1899.521$

$$
\begin{array}{lll}
\Sigma x^{2}=385 & n=10 ; \\
\Sigma y^{2}=411557 & & \\
& & \\
& a= & \frac{\left(\sum y\right)\left(\sum x^{2}\right)-\left(\sum x\right)\left(\sum x y\right)}{n\left(\sum x^{2}\right)-\left(\sum x\right)^{2}}
\end{array}
$$

First, we need to calculate the y-intercept, $a$, and the slope, $b$.

$$
b=\frac{n\left(\sum x y\right)-\left(\sum x\right)\left(\sum y\right)}{n\left(\sum x^{2}\right)-\left(\sum x\right)^{2}}
$$


$a=56.7202$

$b=24.22398$.

The coefficient of correlation:

$$
\begin{aligned}
r & =\frac{n \sum x y-\left(\sum x\right)\left(\sum y\right)}{\sqrt{\left(\sum x^{2}\right)-\left(\sum x\right)^{2}} \sqrt{n\left(\sum y^{2}\right)-\left(\sum y\right)^{2}}} \\
& =0.976787 \\
r^{2} & =0.95414
\end{aligned}
$$

So the linear regression is $\hat{y}=56.7202+24.22398 x$. $r^{2}$ is equal to 0.95414 , which means that about $95.414 \%$ of the response variables are explained by the linear model.

To validate the positivity of the correlation at alpha level of 0.01 , a hypothesis testing is done.

Hypothesis: $H_{o}: \rho<0$,

$H_{a}: \rho>0$ (claim).

Critical value: the alpha value is 0.01 and the degree of freedom is $n-2=8$, so the critical value is $t=2.896$.

T-distribution test statistic:

$$
t=\frac{r}{\sqrt{\frac{1-r^{2}}{n-2}}}=12.9011
$$

Decision: Since the test statistic is greater than the critical value, we rejected the null hypothesis.

Conclusion: The test shows that there is a positive linear correlation between year and housing prices in Beijing from 2005 to 2015.

$$
\begin{aligned}
& \text { Washington: } \\
& \Sigma x=49 \quad \Sigma x^{2}=371 \quad n=7 \text {; } \\
& \Sigma y=1315.705 \quad \Sigma y^{2}=248458.487 \quad \Sigma x y=9367.57 \text {. }
\end{aligned}
$$

Using the same step discussed above, we get:

$a=148.5491$;

$b=5.6298$

$r=0.8741$

$r^{2}=0.7641$.

The linear regression is $\hat{y}=148.5491+5.6298 x$. A hypothesis testing is also carried out to validate the positivity of the correlation at alpha level of 0.01 .

Hypothesis: $H_{0}: \rho \leq 0$,

$H_{a}: \rho>0$ (claim).

Critical value: the alpha value is 0.01 and the degree of freedom is $n-2=5$, so the critical value is $t=3.365$.

T-distribution test statistic:

$$
t=\frac{r}{\sqrt{\frac{1-r^{2}}{n-2}}}=4.024
$$

Decision: Since the test statistic is greater than the critical value, we rejected the null hypothesis.

Conclusion: The test shows that there is a positive linear correlation between year and housing prices in Washington from 2005 to 2014.

\section{Results for I}

The mean comparison hypothesis test shows that the housing price in Beijing is higher than that in Washington (Figures 6-8). Even though the housing price of Beijing is relatively low in 2005 and 2006, it has increased drastically and has far exceeded the housing prices in Washington since 2010. Figure 8 also illustrates that the discrepancies between them tends to be greater in the future. The linear regression test proves that there is a positive linear relationship between time and housing prices for two areas, which means as time goes by, their housing prices are both increasing. However, the slopes of the linear model reflect their different growth rate. 


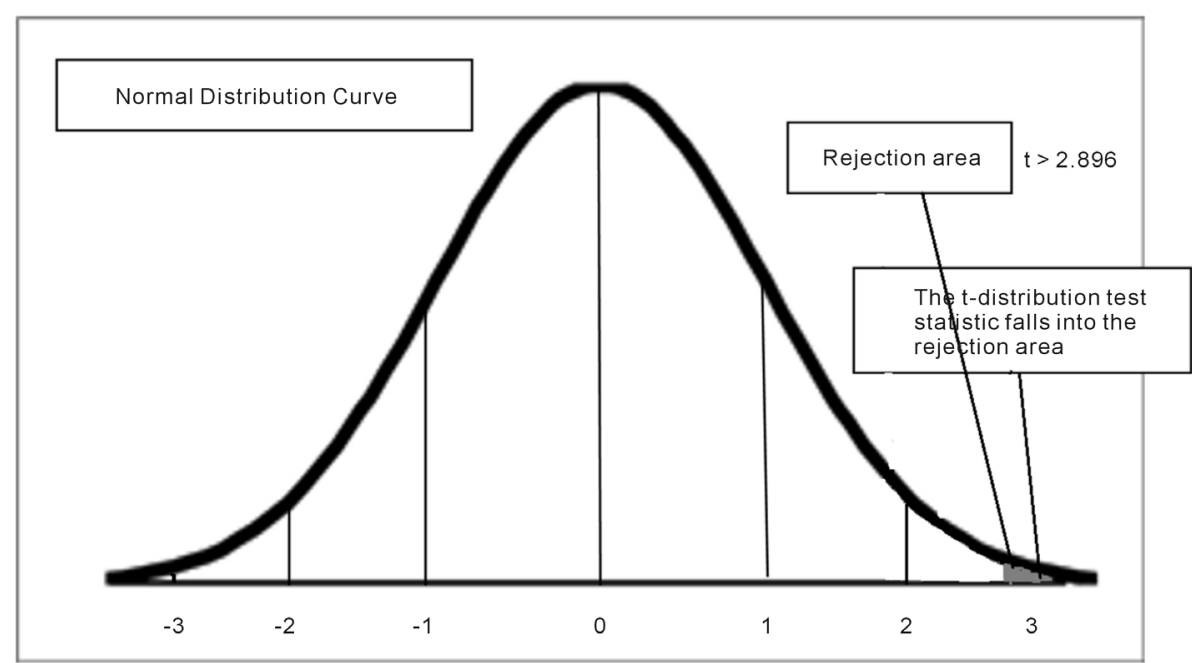

Figure 6. Normal distribution curve.

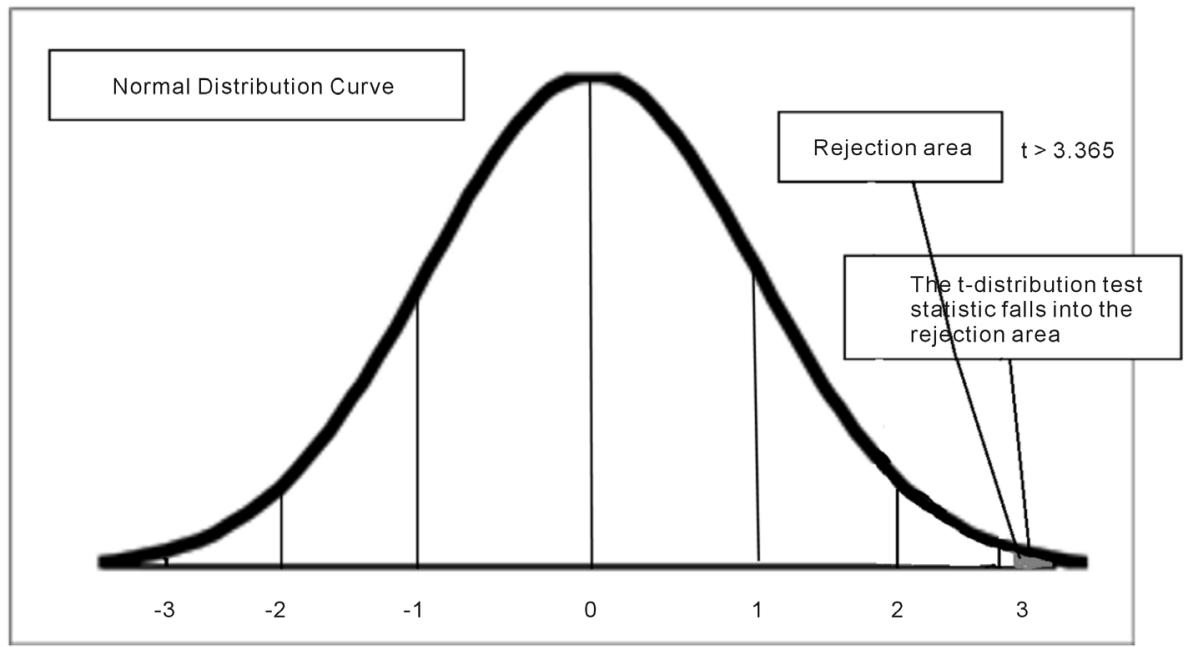

Figure 7. Normal distribution curve.

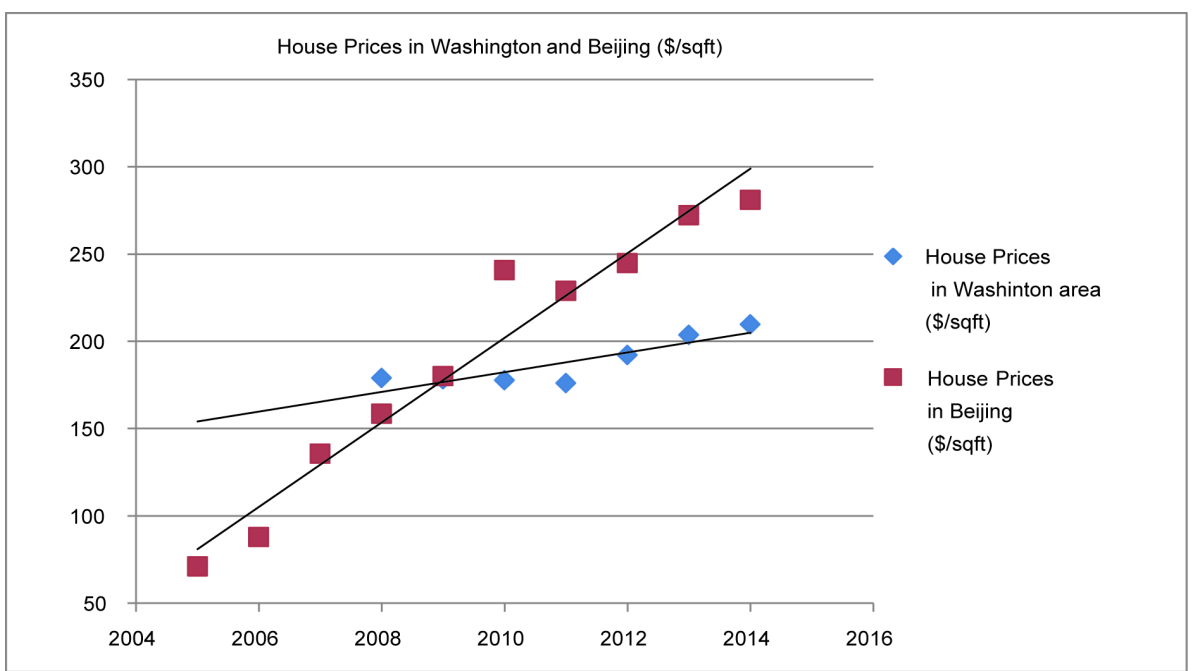

Figure 8. House prices in Washington and Beijing. 
For Beijing, the slope $b$ is 24.22398 , and for Washington the slope $b$ is 5.6298 , which means the housing price in Beijing increases more than four times faster than in Washington.

\subsection{The Comparison of the per Capita Income in Washington and Beijing}

What factor has caused the tremendously high housing price in Beijing? One reasonable proposal is that the income in Beijing is also greater than that in Washington D.C. In order to prove or disapprove the proposal suggested, it is necessary to compare the distribution of per capita income for both cities. A line chart can be used to compare.

$\begin{array}{lll}\text { Data: } & \text { Beijing } & \text { Washington } \\ \text { Min } & 2187.43 & 42,239.5 \\ \text { Median } & 4152.89 & 43,486.00 \\ \text { Max } & 7176.01 & 49,583.00\end{array}$

\section{Results for II}

From the data (Figure 9), it is clear that the per capita income in Beijing is far less than that in Washington. Even the minimum of Washington, 42,239.5 dollars, is six times more than the maximum of Beijing, 7176.01 dollars. The average per capita income in Washington DC. from 2005 to 2014 is $\$ 43,834.1$ and income in Beijing is $\$ 4449.28$, which is almost one tenth of that in Washington. The graph also demonstrates that although the wages have risen in China, China still has a long way to go before its per capita income catches up with that of the U.S. This result disapproves the proposal mentioned above that it is the high income in Beijing that results in its expensive housing price. Therefore, further discussion is needed in order to find the reason behind the high price.

\subsection{The Limited Land Resource Leads to the Conflict between Supply and Demand}

In a market economy, the price of a product depends on the supply-demand relationship, which is also the main reason of the increase in housing price. According to the 2014 data from the National Bureau of Statistics of China, the urbanization percentage is 54.77 in 2014, whereas the percentage was only 36.22 in 2000 . The urban population is 749.16 million, an increase of 18.05 million people from the previous year. We can use a linear regression model to determine trend of the urbanization rate and its strength (Figure 10).

\section{Method: Linear Regression Model}

In this case, we also use 1 through 15 to represent 2000 to 2014.

$$
\begin{array}{lll}
\Sigma x=120 & \Sigma x^{2}=1240 & n=15 ; \\
\Sigma y=679.17 & \Sigma y^{2}=31228.9255 & \Sigma x y=5796.01 .
\end{array}
$$

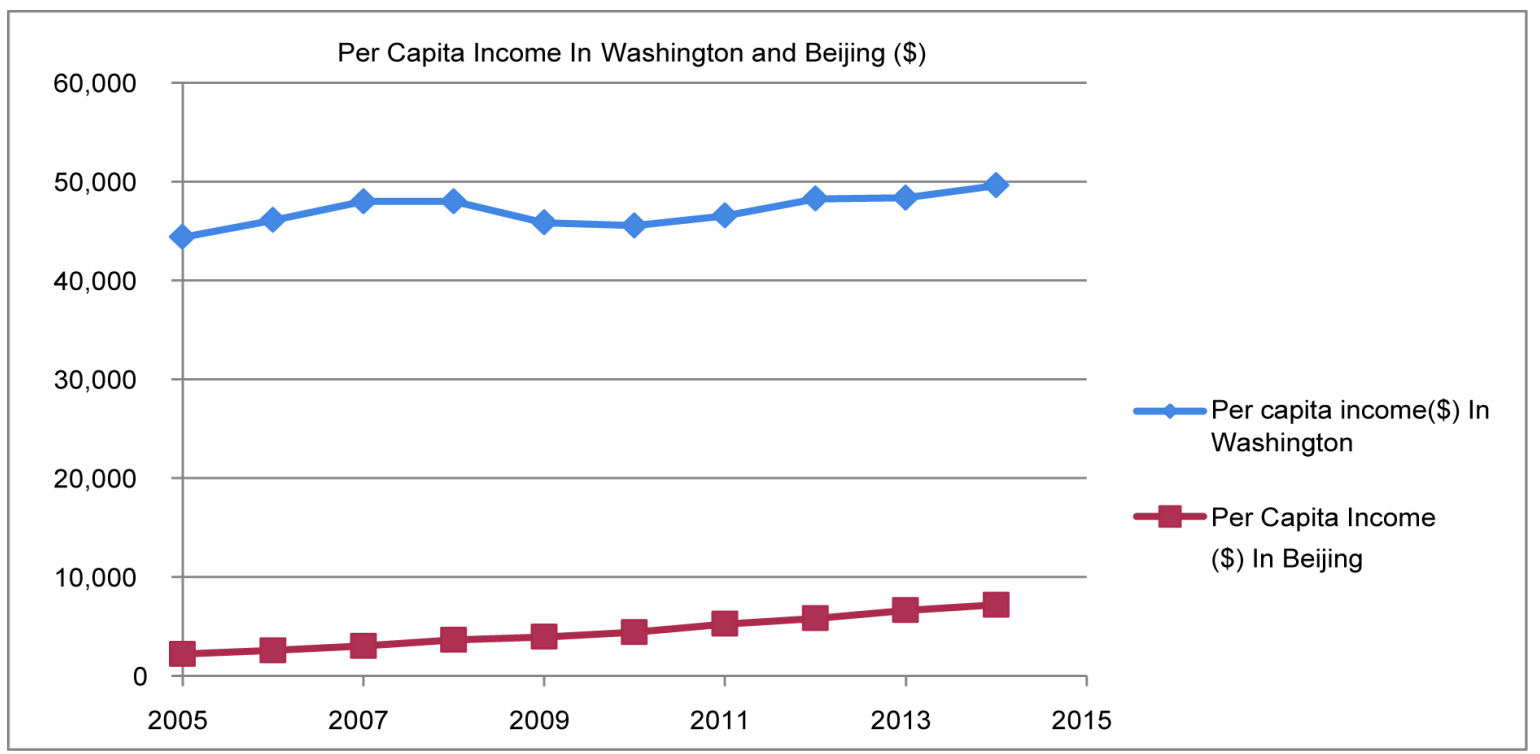

Figure 9. Per capita income in Washington and Beijing from 2005 to 2014 [5] [14]. 


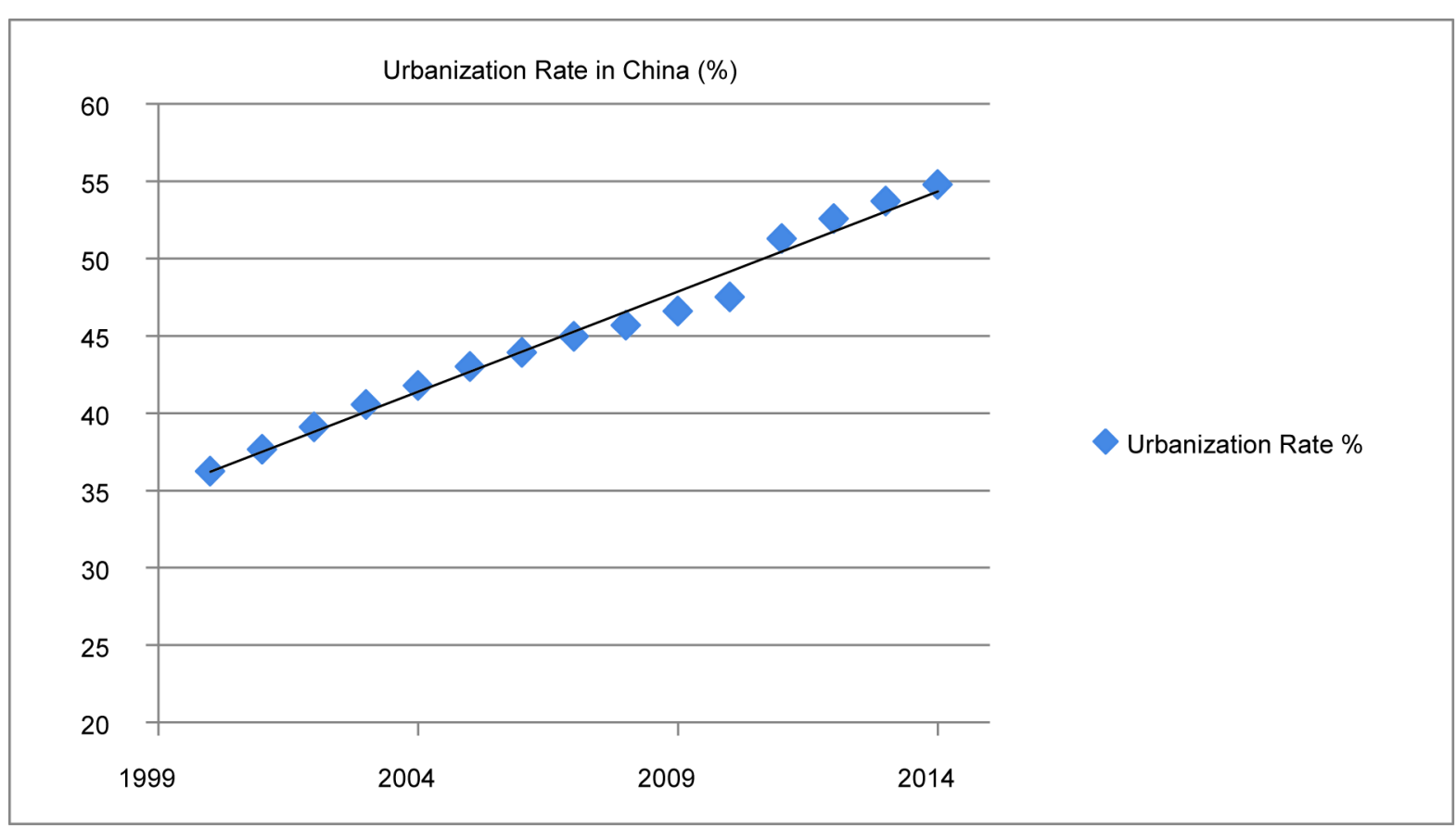

Figure 10. Urbanization rate in China from 2000 to 2014 [5].

First, we need to calculate the y-intercept, $a$, and the slope, $b$.

$$
\begin{aligned}
& a=\frac{\left(\sum y\right)\left(\sum x^{2}\right)-\left(\sum x\right)\left(\sum x y\right)}{n\left(\sum x^{2}\right)-\left(\sum x\right)^{2}} \\
& b=\frac{n\left(\sum x y\right)-\left(\sum x\right)\left(\sum y\right)}{n\left(\sum x^{2}\right)-\left(\sum x\right)^{2}}
\end{aligned}
$$

$a=34.9166$

$b=1.295$.

The coefficient of correlation:

$$
\begin{aligned}
r & =\frac{n \sum x y-\left(\sum x\right)\left(\sum y\right)}{\sqrt{n\left(\sum x^{2}\right)-\left(\sum x\right)^{2}} \sqrt{n\left(\sum y^{2}\right)-\left(\sum y\right)^{2}}} \\
& =0.9918 \\
r^{2} & =0.983
\end{aligned}
$$

So the linear regression is $\hat{y}=34.9166+1.295 x . r^{2}$ is equal to 0.9918 , meaning that about $99 \%$ of the response variables are explained by the linear model. The equation also reflects that the urbanization rate is approximately $1.3 \%$ each year and this trend seems to continue. If the urbanization level reaches $70 \%$, the urban population would increase by 400 million. The conflict between the constantly expanding universe of house buyers and the limited land supply would undoubtedly result in the rising housing price.

\subsection{The Reasons for the Population Migration to Beijing}

Population migration refers to the movement by people with the purpose of settling temporarily or permanently in the new location. Population migration is an inevitable phenomenon in the process of social development. Generally speaking, the larger the city is, the greater the force of attraction to migration is. The following analysis proposes two reasons for the human migration to Beijing: the difference in the cities functions and the unba- 
lanced regional development.

\subsubsection{The Discrepancies of the City Functions}

The Qing dynasty unified China and established a centralized empire in 221 BC. During its reign over China, the Qing dynasty created an imperial state unified by highly structured central government and a stable economy able to support a strong military force. Even though the centralization ended in 1912, as the Xinhai Revolution overthrow China's last imperial dynasty, it still generates tremendous influence on China's society [15]. As the last of the Four Great Ancient Capitals of China, Beijing has been the political, cultural, and educational center of the country for centuries. Beijing is renowned for its opulent historical buildings, art treasures, famous universities, sporting events, and economic zones. In comparison, the city function of Washington lacks diversity. Many people's impression of Washington remains simple-the centers of all three branches of the federal government. This difference can be reflected upon four aspects, including economy, education, tourism, and sports.

The rapid economic growth serves as the main reason for the human migration. The economic performance of two cities can be compared through the gross domestic product. The growth rate of the GDP is found by calculating the slope of linear regression model.

\section{Method: Linear Regression Model}

Beijing:

Using 1 through 10 to represent 2005 to 2014, the following data can be obtained:

$$
\begin{aligned}
& \Sigma x=55 \quad \Sigma x^{2}=385 \quad n=10 \text {; } \\
& \Sigma y=2094.595 \quad \Sigma y^{2}=514416.8187 \quad \Sigma x y=14007.82 .
\end{aligned}
$$

The $y$-intercept, $a$, and the slope, $b$ are calculated using the equation bellow:

$$
\begin{aligned}
& a=\frac{\left(\sum y\right)\left(\sum x^{2}\right)-\left(\sum x\right)\left(\sum x y\right)}{n\left(\sum x^{2}\right)-\left(\sum x\right)^{2}} \\
& b=\frac{n\left(\sum x y\right)-\left(\sum x\right)\left(\sum y\right)}{n\left(\sum x^{2}\right)-\left(\sum x\right)^{2}}
\end{aligned}
$$

$a=43.623$

$b=30.152$.

The coefficient of correlation:

$$
\begin{aligned}
r & =\frac{n \sum x y-\left(\sum x\right)\left(\sum y\right)}{\sqrt{n\left(\sum x^{2}\right)-\left(\sum x\right)^{2}} \sqrt{n\left(\sum y^{2}\right)-\left(\sum y\right)^{2}}} \\
& =0.9955 \\
r^{2} & =0.9910
\end{aligned}
$$

So the linear regression is $\hat{y}=43.623+30.152 x . r^{2}$ is equal to 0.9910 , which means that more than $99 \%$ of the response variables are explained by the linear model. The slope shows that GDP in Beijing grows at a rate of 30.152 billion dollars per year.

Washington:

Data:
$\Sigma x=55$
$\Sigma x^{2}=385$
$n=10$
$\Sigma y=1003.59$
$\Sigma y^{2}=100873.8579$
$\Sigma x y=5626.79$.

Using the same equation, we can get the slope $b=1.2975$. The $y$-intercept $a=93.223$.

The coefficient of correlation:

$$
\begin{aligned}
r & =\frac{n \sum x y-\left(\sum x\right)\left(\sum y\right)}{\sqrt{n\left(\sum x^{2}\right)-\left(\sum x\right)^{2}} \sqrt{n\left(\sum y^{2}\right)-\left(\sum y\right)^{2}}} \\
& =0.9479 \\
r^{2} & =0.8986
\end{aligned}
$$


So the linear regression is $\hat{y}=93.223+1.2975 x$. $r^{2}$ is equal to 0.8986 , indicating that about $90 \%$ of the response variables are explained by the linear model. The slope shows that GDP in Washington grows at a rate of 1.2972 billion dollars per year.

The difference between their economy growth rates reflects the effect of rapid economic development on population of Beijing. In most cases, people move to big cities with the purpose of more ideal employment opportunities, thereby improving their living standards. The abundance of the employment and entrepreneurship opportunities leads to the human migration. The migration increases labor supply and promotes the concentration of human resources, which then attracts investment and consumption and impels the city's economy, causing a chain effect.

Another significant factor is education. With the development of society, people gradually realize that education is a vital factor in the country's economic and social progress, and thus start to place immense value on education. Parents are willing to spending lots of money to send their children to the best colleges. Out of this concern, some people choose to move to cities with rich education options.

According to the data, six of the top 30 universities in China are situated in Beijing, including Beking University (2), Tsinghua University (3), Renmin University of China (12), Beihang University (21), Beijing Foreign Studies University (25), and Beijing Normal University (28) [16]. Three of the top 35 colleges in America is in Washington and its surrounding areas, which are Johns Hopkins University, MD (12), Georgetown University, DC (21), and University of Virginia, VA (23) [17]. There isn't a huge difference between the concentration of good colleges in Beijing and Washington, but what enlarges the difference in higher education resource is the total number of colleges in China and America. There are approximately 4140 universities in the United States, but only about 2286 in China. However, the population in China is about 1.4 billion, and the population in U.S. is about 0.3 billion [18] [19]. This fact results in the fierce competition among Chinese students and makes good colleges even more valuable. In addition, Beijing's university undergraduates reached around 210,000 each year. The majority of them tend to remain working and living in Beijing they graduate, which will inevitably involve with purchase or rental housing.

Besides, as an internationally renowned tourist city, Beijing has abundant tourism resources. Famous for its opulent palaces, parks, gardens, temples, and gates, Beijing attracted 257 million domestic tourists in 2014, while Washington only received 18.34 domestic visitation [20]. The developed tourist industry has promoted the economic development in Beijing by creating new job opportunities.

Major sporting events also play a crucial role in a city’s economy. Beijing has hosted numerous international and national sporting events, including the notable 2008 Summer Olympic and Paralympic Games. Whereas Washington has rarely held "mega-sports events" like the World Cup or Olympics. Major sporting events can bring multiple benefits to the hosting city, which include improving the image and popularity of the city, promoting the development of catering and tourist industry, promoting employment, contributing to the urban construction, and so on. A city's reputation and popularity would largely affect people's decisions when they are choosing their residence.

\subsubsection{The Unbalanced Regional Development}

Since the open-door policy of the late 1970s, China has achieved magnificent economic growth. However, the fruits of the achievement have not been distributed fairly to each region. In the early stages of the reform, the Chinese government introduced preferable policies to coastal regions, with the aim of attracting investment from abroad. This strategy has contributed enormously to the economic growth and particularly to export industry. However, China's foreign direct investment policy has been highly concentrated in the eastern coastal cities, causing regional inequalities [21]. Table 2 is the list of Chinese administrative divisions by disposable income per capita. It can be seen that the top 9 cities in the ranking are all eastern coastal cities. Only these nine cities and Inner Mongolia have a per capita income higher above the mean, \$3295. Leaders in China expected that the development of the eastern regions would ultimately lead the rest of the economy to expand. However, the spill-over effect that would promote the economy in the inland areas did not occur as they expected.

In order to control the rising regional inequality, the Chinese government put the "western development strategy" in to practice in 1998, and implemented "north-east revival strategy" in 2003. However, despite of great endeavor, the huge gap still exists. The per capita incomes of the western regions (highlighted in blue) are still very low [21].

China's regional disparities, to a great extent, are due to the policies by central government. But it is becoming 
Table 2. The per capita income of Chinese administrative divisions [5].

\begin{tabular}{|c|c|c|c|c|c|}
\hline Provinces & RMB & $\$$ & Provinces & RMB & $\$$ \\
\hline Shanghai & 45,966 & 7510.784314 & Heilongjiang & 17,404 & 2843.79085 \\
\hline Beijing & 44,489 & 7269.444444 & Anhui & 16,796 & 2744.444444 \\
\hline Zhejiang & 32,658 & 5336.27451 & Jiangxi & 16,734 & 2734.313725 \\
\hline Tianjin & 28,832 & 4711.111111 & Hebei & 16,647 & 2720.098039 \\
\hline Jiangsu & 27,173 & 4440.03268 & Shanxi & 16,538 & 2702.287582 \\
\hline Guangdong & 25,685 & 4196.895425 & Ningxia & 15,907 & 2599.183007 \\
\hline Fujian & 23,331 & 3812.254902 & Shanxi & 15,837 & 2587.745098 \\
\hline Liaoning & 22,820 & 3728.75817 & Sichuan & 15,749 & 2573.366013 \\
\hline Shandong & 20,864 & 3409.150327 & Henan & 15,695 & 2564.542484 \\
\hline Inner Mongolia & 20,559 & 3359.313725 & Guangxi & 15,557 & 2541.993464 \\
\hline Chongqing & 18,352 & 2998.69281 & Xinjiang & 15,097 & 2466.830065 \\
\hline Hubei & 18,283 & 2987.418301 & Qinghai & 14,374 & 2348.69281 \\
\hline Hunan & 17,622 & 2879.411765 & Yunnan & 13,772 & 2250.326797 \\
\hline Jilin & 17,520 & 2862.745098 & Guizhou & 12,371 & 2021.405229 \\
\hline Hainan & 17,476 & 2855.555556 & Gansu & 12,185 & 1991.013072 \\
\hline Heilongjiang & 17,404 & 2843.79085 & Tibet & 10,730 & 1753.267974 \\
\hline Hainan & 17,476 & 2855.555556 & & & \\
\hline
\end{tabular}

increasingly difficult for the government to control the economy, as the market economy mechanisms generate great influence on Chinese economy in recent years. Chinese leadership has paid substantial attention on the regional disparities, but further reforms are needed in order to make government's policies effective. For now, the unbalanced development in China is one of the reasons for the population migration to big cities. (Figure 11, Table 2)

\subsection{The Influence of Cultural Traditions}

China's traditional culture emphasizes the importance of owning individual housing, which is often considered as a sign of economic independence. Generally, younger generation must have its own house before marriage, which has gradually become a necessary precondition of marriage. Rental housing, in comparison, is an inferior option. What is more, the incomplete social security system made housing a proactive tool. Renting a house and then receiving the rent would bring people a sense of economic security, even though the rental yield is not high. In Beijing, the rental yield is only $2.09 \%$ for the city center and $2.33 \%$ outside city center, while its house ownership reached more than $80 \%$, compared to $63.6 \%$ in Washington [23] [24].

\subsection{The Government's Policies}

The Chinese government's housing policy is one of the important factors that affect the Chinese housing market. Figure 12 demonstrates how the Chinese housing market reacted differently compared to housing market in U.S. to the 2008-2009 global financial crisis. In fact, the Chinese government's policies contributed to the fast recovery and continued growth in China's housing market. American central bank implemented quantitative easing to stimulate the economy. Quantitative easing is a policy used when normal monetary policy is ineffective. Central bank buys securities from commercial banks and other financial institutions, with the purpose of raising the value of these assets and lowering interests' rates, while increasing the money supply [25]. One of the major effects of this policy is the bubble burst of American housing market, with its housing market investment dropped 


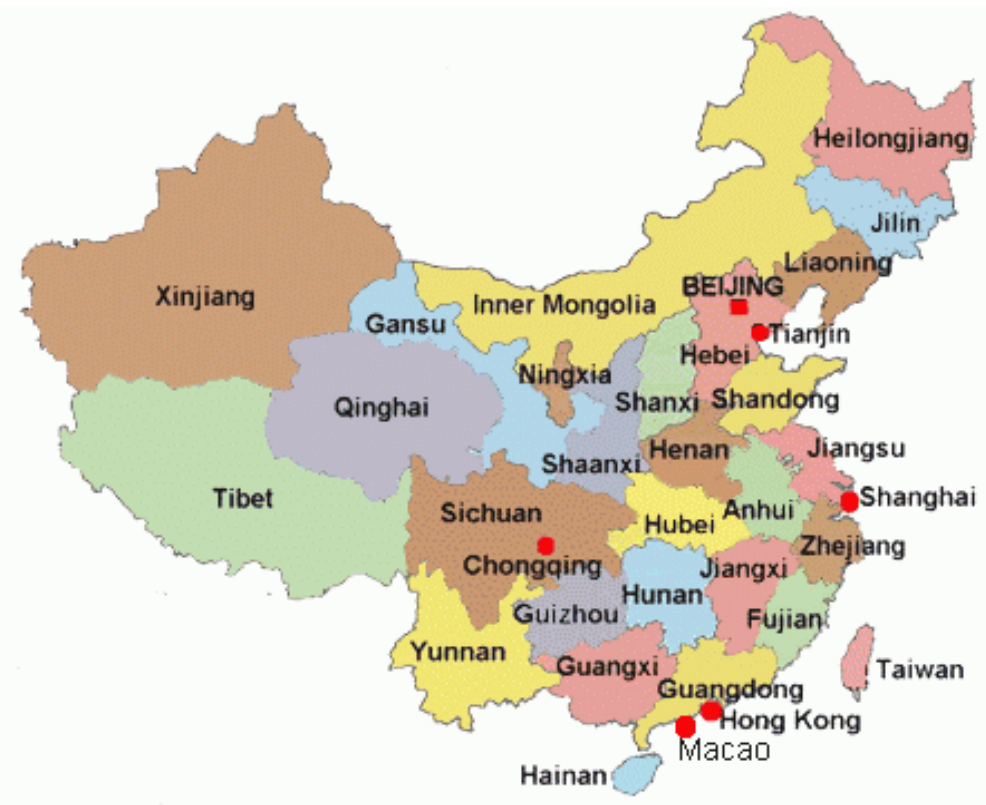

Figure 11. Map of Chinese provinces [22].

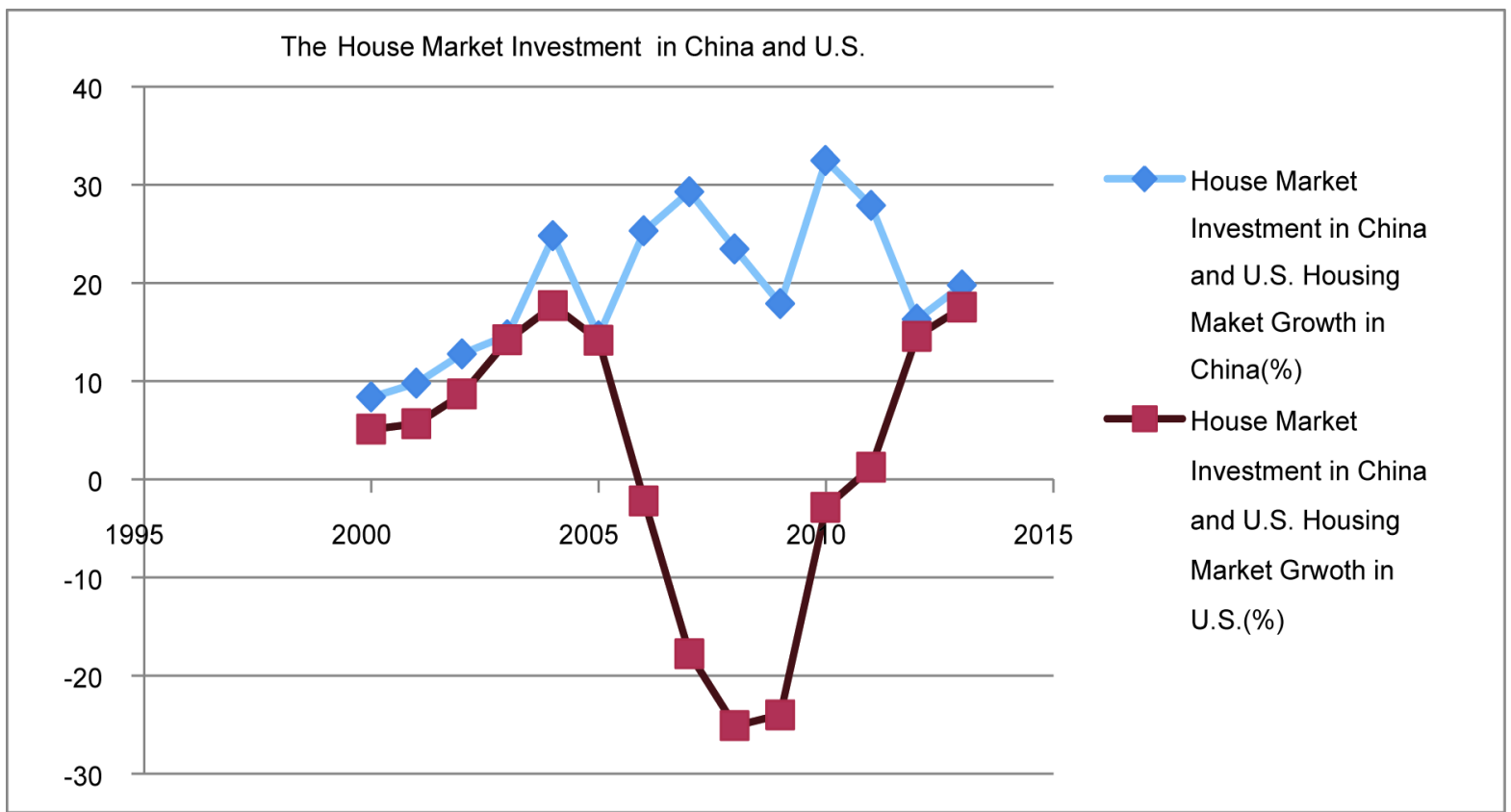

Figure 12. The housing market investment in China and U.S. [26].

to $-25.09 \%$ in 2008 . While Chinese government implemented different strategies. In terms of monetary policies, the central government lowered the interest rate by $0.81 \%$ within two month. In terms of tax adjustments, by the end of 2008 the deed tax dropped to 1\%, and the land value increment tax was removed on all personal purchases of property under 90 square meters. Besides, for all first-time house purchases, the mortgage interest rate was lowered by $20 \%$ [26]. In addition, both the central government and the local governments in first-tire cities provided subsidies to support housing market, such as lowing fees associated to purchases. All of these actions may be conducive to the strong momentum that maintained the growth of Chinese housing market after the financial crisis. 


\subsection{The Unreasonable Structure of Housing Supply}

The data from National Bureau of Statistics of China shows that the investment and supplying structure of commercial housing are not reasonable enough. The constant decrease in the percentage of affordable housing and the increase in the housing vacancy rate became one of the reasons for the high housing prices in the last few years. Many developers are interested in big apartments and luxurious houses, especially in first-lire cities like Beijing where the rich often choose to reside, causing the significant drop in the ratio of affordable houses and thus affecting the structure of commercial housing supply. However, due to the existence of a group of wealthy people who are able to purchase these expensive houses, the housing prices would only keep rising. In order to solve the housing difficulties of low-income families in urban areas, the Chinese government has introduced a series of policies with the focus on low-rent housing system [27].

\subsection{The Investment Demand}

Investors have driven up property prices, in some case buying hundreds of empty houses, as they believe housing is a good investment, preferable to bonds and stocks. The saving rate in China is high. With fears of inflation and the anticipation of rising house prices, not only wealthy households but also middle class consider purchasing houses as a means of hedging and investment. According Xinhua News Agency, 62 percent of householders would choose to invest in housing market if they have enough savings. Such preference directly results in the skyrocketing housing prices in Beijing.

\subsection{The Problems behind the Chinese Housing Market}

Morgan Stanley, a renowned American multinational financial services corporation, once pointed out in its report that Chinese housing buyers whose personal income is less than one thirtieth of Americans' are affording the same housing price as U.S. housing buyers. The income gap may narrowed today, but it still exists. Figure 13 is about the annual housing price to income ratio between the U.S. housing market and the Chinese housing market. Based on the graph, we can see that the housing price to income ratio in China is much higher compared to the U.S. housing market. According to the World Bank's Studies, a relatively healthy housing price to income ratio should range from 3 to 5. In this case, the U.S. housing market can be evaluated as a healthy one. Whereas the homes in China are overpriced relative to the international standards. In Beijing, the ratio even reached up to 19.9 in 2014. The drastic growth of housing price in China has become a dark shadow brooding over people’s

\section{HOUSING PRICE TO INCOME RATIO}

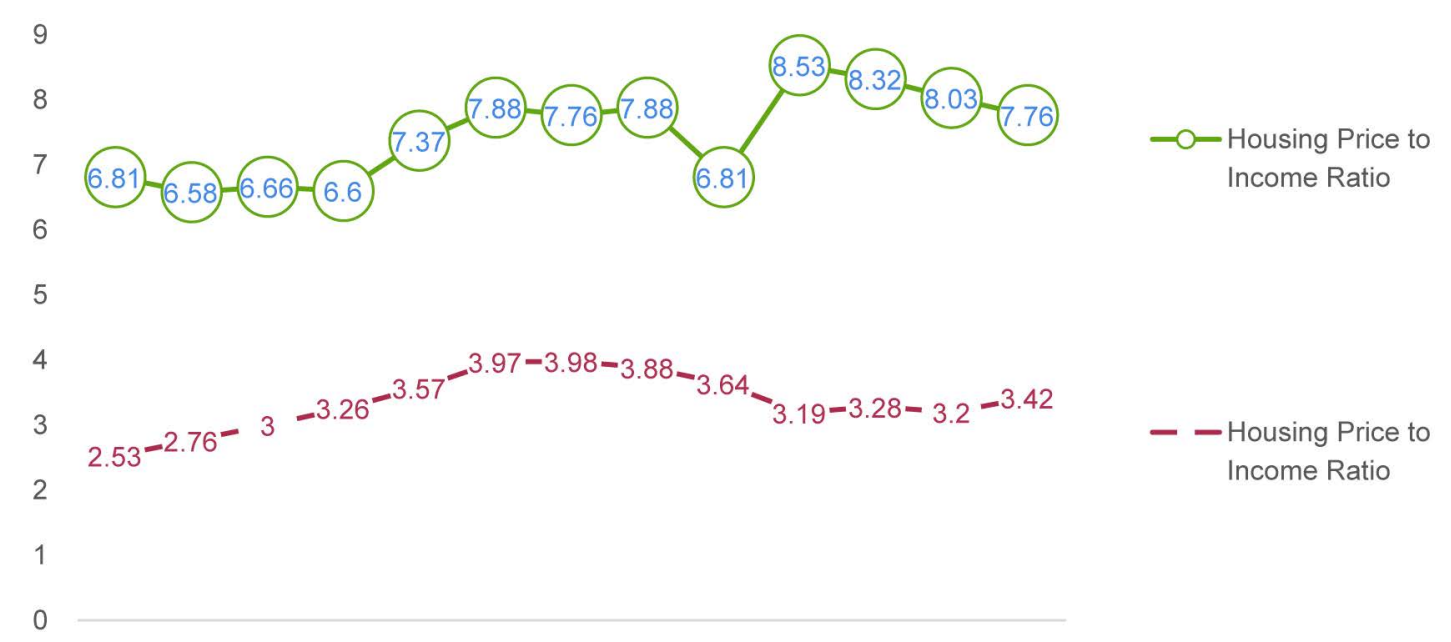

2000200120022003200420052006200720082009201020112012

Figure 13. Housing price to income ratio in China and U.S. from 2000 to 2012 [26]. 
heart. The constantly rising price has already exceeded common people's affordability, especially to low-income families that are in dire need of a home but are not able to afford it. This fact would ultimately affect the economic and even social stability if the problem behind Chinese housing market were not to be eased.

One more thing that needs to be noticed and also emphasized is that it is difficult to actually slow the increase in housing price in China in the next few years. As long as the economy keeps a sustainable and rapid growth, the price would remain high. To find the per capita growth trend in Beijing, a quadratic regression model is found.

\section{Method: Exponential Regression Model}

For an exponential regression model, $y=a^{*} b^{x} . r^{2}$, the coefficient of determination indicates how well the exponential model fits the data.

Using the data in Tables A1-A7 (Shown in Appendix), we get:

$a=1039.46$

$b=1.14$

$r=0.9976$

$r^{2}=0.9954$.

The exponential regression is: $y=1039.46 *(1.14)^{x}$. The $r^{2}$ equals to 0.9954 , which means that more than $99 \%$ of data fit the exponential model. As Figure 14 illustrates, the growth rate of per capita income in Beijing tends to increase each year. Such economic growth could only stimulate the housing market, causing the price to continue rising. Unless certain effective policies were to be implemented, the growth of housing price is inevitable.

\section{Conclusions}

Since Deng Xiaoping's economic reform in 1978, China has become one of the world's fastest-growing economies and is predicted to be one same level as the United States, which has dominated the global economy since the fall of the Soviet Union. One of the direct results of the reform is the rapid growth of Chinese housing market. The two-sample mean hypothesis testing and the linear regression show that the housing price in Beijing has already surpassed than in Washington D.C. and continues rising at a high rate. One direct and seemingly reasonable conjecture is that the personal income in Beijing is higher. However, by comparing the line chart and data, it is clear that the per capita income in Beijing is far less than that in Washington, which disapproves the proposal mentioned earlier.

A series of factors have contributed to the rapid growth of the housing price in Beijing. The primary reason is

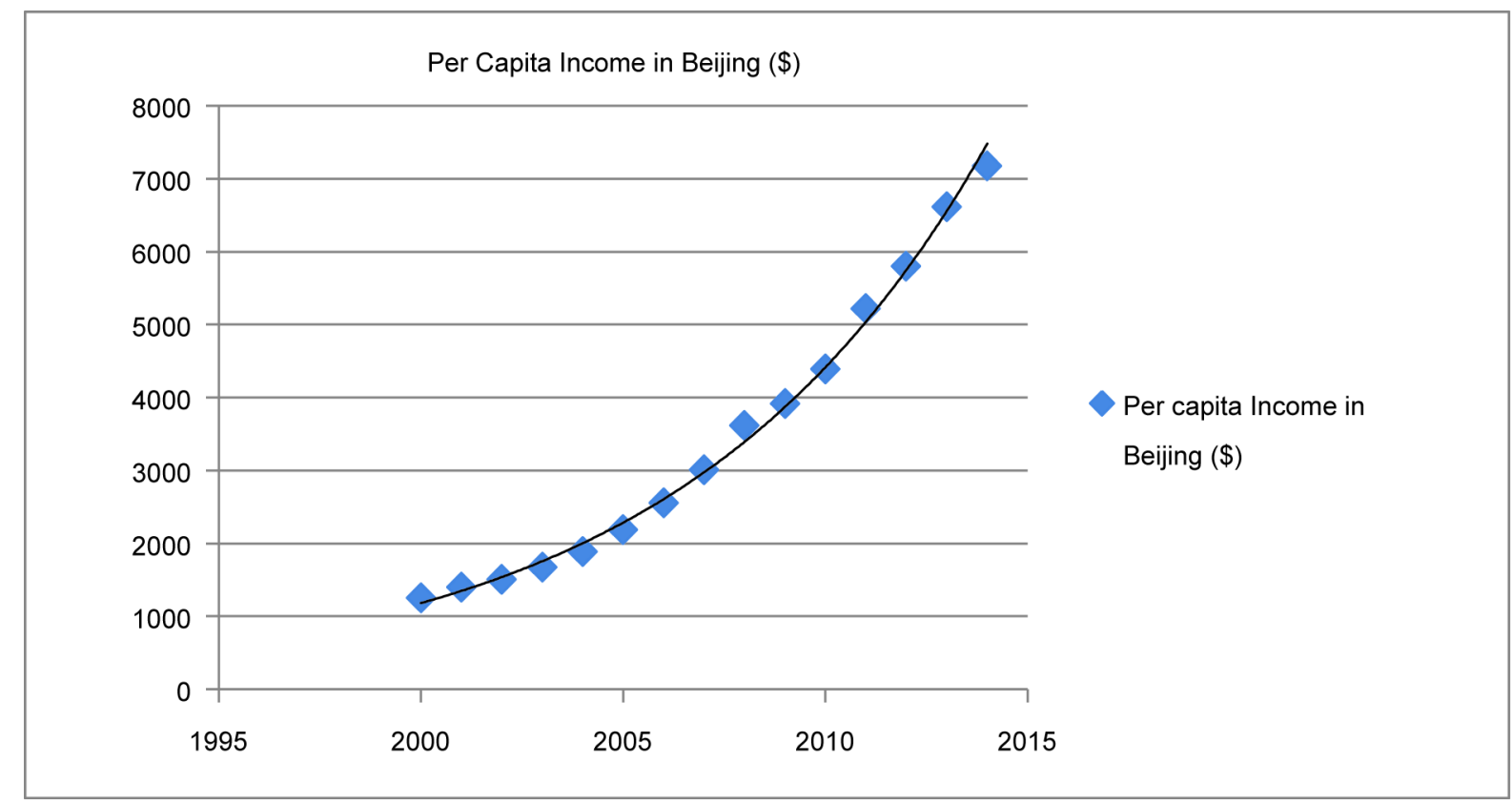

Figure 14. Per capita income in Beijing [5]. 
the limited land resource which leads to the conflict between supply and demand. The linear regression model for the urbanization rate in China reflects the strength of population migration to big cities and then two reasons are proposed: the discrepancies of the city functions in Beijing and Washington and the unbalanced regional development in China.

China's history of being a centralized empire has established Beijing as a political, cultural, and educational center. In terms of economy, the linear model is used to compare the GDP growth rate in two cities and the result shows that the GDP is Beijing growing at a rate of about 30 billion dollars per year, while the growth rate in Washington is approximately 1.3 billion dollars per year. Many people, with the hope of finding more desirable job opportunities, choose to migrate to Beijing, which in turn increases labor supply, investment, and consumption, and thus attracts more immigrants, causing an incessant chain effect. Besides, the high concentration of top colleges, the renowned tourism, and its identity as the host of many major international sporting events are all the factors that have promoted the population migration to Beijing. Another important reason for the migration is China's regional disparities, which is in part resulted from the policies put forth by the central government during the early stage of China's economic reform. This idea is substantiated by looking at the per capita income of Chinese administrative divisions.

Other factors also lead to the high housing price in Beijing, which includes the Chinese cultural traditions that emphasize the necessity of owing individual house, the government's policies that support the real estate market, the lack of affordable house for low-income families, and people's preference to invest in housing market. The reasons behind the high housing prices are complicated, but the comparison of the data exposes the problem underneath the seemingly prosperous housing market in China.

The line chart of the annual housing price to income ratio between the U.S. housing market and the Chinese housing market demonstrates that the housing price in China has greatly exceeded common people's affordability. People of great fortune are able to earn more money by investing in housing market and thus become richer. In opposite, low-income people would have no home to live, which may cause social instability. What makes the problem worse is the sustainable and drastic economic growth. The per capita income in Beijing follows a quadratic regression rather than a linear one. This result means that as long as the Chinese economy continues its growth trend, the increase in the housing price is inevitable.

There is one more thing needs to be compared-the houses that people actually purchase. Figure 15 shows the floor plan of a 1.0784-million-dollar apartment in China. The floor area is $1292 \mathrm{sqft}$ and it contains 2 bathrooms, 1 living room, two bedrooms and one extra room for entertainment. Figure 16 is a 0.9 -million-dollar

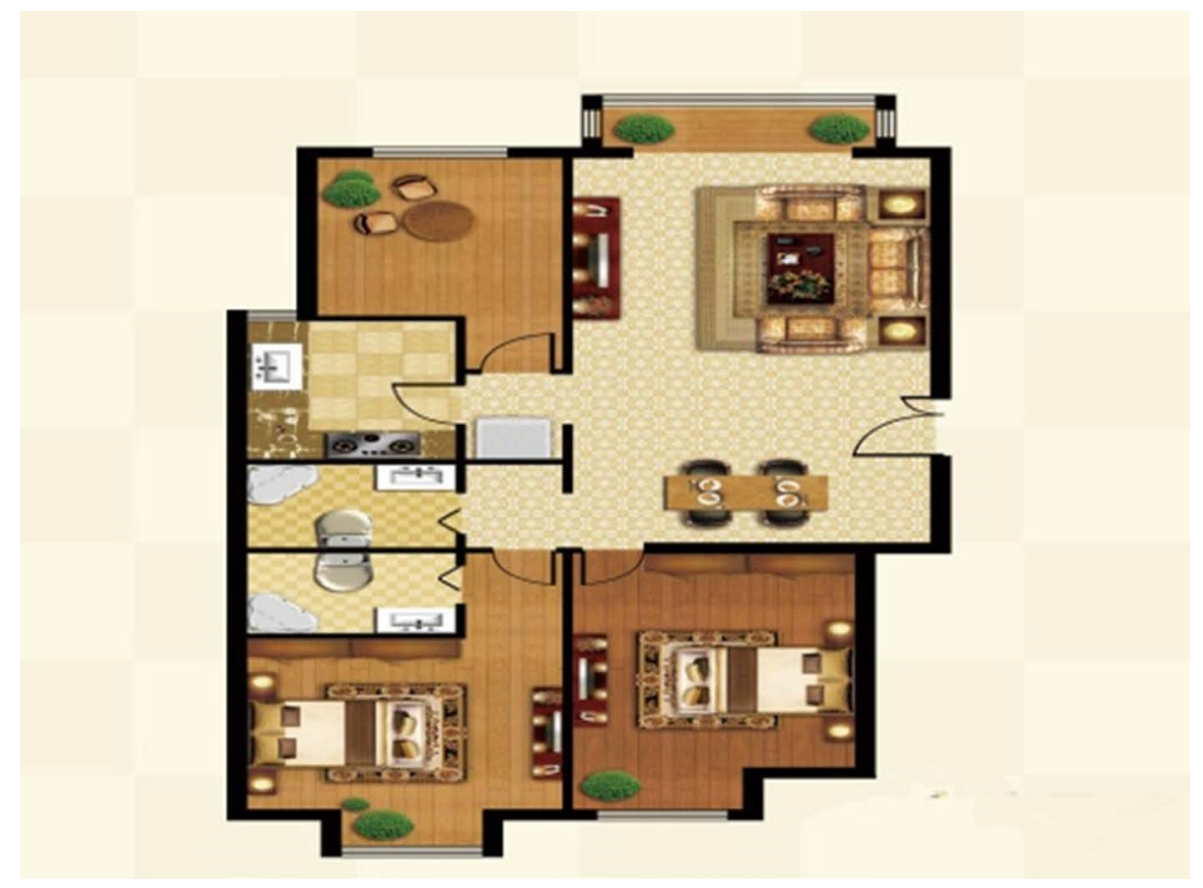

Figure 15. House in Beijing [28]. 


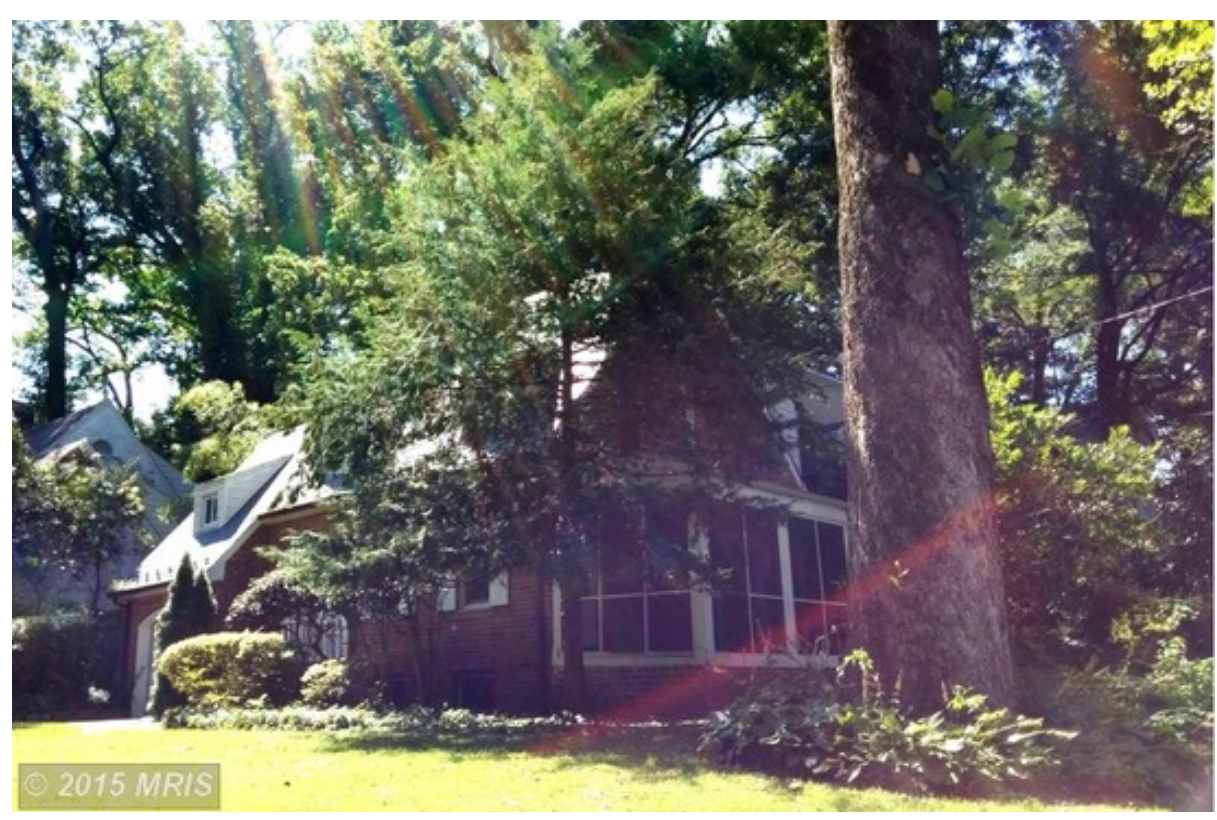

Figure 16. House in Washington [29].

house in Washington. It is 1654 sqft and has 4 bedrooms and 3 bathrooms. Comparing the numbers, it is not difficult to find that money is more valuable in the U.S. housing market. Paying the same amount of money, house buyers are able to purchase a more commodious and better-looking home in Washington D.C. Besides, there is a 70-year lease/land-use rights for commercial residential housing expires in China. After the expiration of the 70 years of land-use, the land is returned to the country, which implies the expiration of ownership of the entire building. To reapply for land-use rights requires paying an additional transfer fee, but how much needs to be paid hasn't been decided. However, in the U.S., house would become permanent personal possession once bought and could be passed down from generation to generation as family inheritance.

Even though this study indicates that China's housing market is currently facing a very problematic condition, compared with American's relatively stable and healthy housing market, what should be also acknowledged is the fact that China, as one of the most populated and fast-development countries, does have a social and economic structure that is very unusual due to historical reasons, and the gradual transition does take time to take place. However, in order to ameliorate the current situation, Chinese government still needs to take more effort to provide more positive adjustments to the economy. Compare with America, whose power is shown both by the numbers like GDP and per capita income and by people's living standard. China still has a long way to go before it could eventually have an economy that is competent on the global stage not only in terms of its rate of growth, but also in terms of its healthiness and long-term stability.

\section{References}

[1] World GDP (Nominal) Ranking (2015) Statistics Times. http://statisticstimes.com/economy/world-gdp-ranking.php

[2] History of World GDP (2010) The Big Picture. http://www.ritholtz.com/blog/2010/08/history-of-world-gdp/

[3] Kumar, R. (2015) China to Overtake US as World's Largest Economy by 2030. News Everyday. http://www.newseveryday.com/articles/13659/20150414/china-overtake-worlds-largest-economy-2030.htm

[4] Catching the Eagle. (2013) The Economist. http://www.economist.com/blogs/graphicdetail/2014/08/chinese-and-american-gdp-forecasts

[5] Statistical Data (2015) National Bureau of Statistics of China. http://www.stats.gov.cn/english/

[6] The Latitude and Longitude of Beijing, China (2015) Travel Math. http://www.travelmath.com/cities/Beijing+China

[7] Location of Washington DC (2015) City Latitude Longitude. http://www.worldatlas.com/webimage/countrys/namerica/usstates/dclatlog.htm

[8] United States Census Bureau (2015) Washington Quick Facts from the US Census Bureau. 
http://quickfacts.census.gov/qfd/states/53000.html

[9] Service Area (2015) Goel Service. http://www.goelwastewater.com/service-area.asp

[10] Washington Home Prices and Home Values (2015) Zillow. http://www.zillow.com/wa/home-values/

[11] Zillow (n.d.) Virginia Home Prices \& Home Values. http://www.zillow.com/wa/home-values/

[12] Zillow (n.d.) West Virginia Home Prices \& Home Values. http://www.zillow.com/wa/home-values/

[13] Zillow (n.d.) Maryland Home Prices \& Home Values. http://www.zillow.com/wa/home-values/

[14] Statista (n.d.) Washington: Disposable Personal Income 1990-2014. http://www.statista.com/statistics/306018/washington-disposable-persona-income/

[15] Office of the Historian (n.d.) The Chinese Revolution of 1911. https://history.state.gov/milestones/1899-1913/chinese-rev

[16] Top Universities in China 2015 Reviews \& Rankings (n.d.) 4 International Colleges and Universities. http://www.4icu.org/cn/

[17] US News (n.d.) National Universities Rankings. http://colleges.usnews.rankingsandreviews.com/best-colleges/rankings/national-universities?int=9ff208

[18] World Meters (n.d.) China Population (LIVE). http://www.worldometers.info/world-population/china-population/

[19] United States Census Bureau (n.d.) US and World Population Clock. http://www.census.gov/popclock/

[20] Washington DC (2015) DC Travel Rally Announces Impact of Hospitality \& Tourism Industry. http://washington.org/press/dc-travel-rally-announces-impact-hospitality-tourism-industry

[21] Fan, S., Kanbur, R. and Zhang, X. (2009) China’s Regional Disparities: Experience and Policy. Cornell University. http://www.kanbur.aem.cornell.edu/papers/FanKanburZhangLimPaper.pdf

[22] Weather Underground (n.p.) Map of Chinese Provinces. http://www.wunderground.com/blog/weatherhistorian/archive.html?year=2013\&month=07

[23] Numbeo (n.d.) Property Prices in Beijing, China. http://www.numbeo.com/property-investment/city_result.jsp?country=China\&city=Beijing

[24] Trading Economics (n.d.) Home Ownership Rate for Washington—United States. http://www.tradingeconomics.com/united-states/home-ownership-rate-for-washington-percent-a-na-fed-data.html

[25] Investopedia (2009) Quantitative Easing Definition. http://www.investopedia.com/terms/q/quantitative-easing.asp

[26] Wu, H. (2015) Looking into the China Housing Market Bubble Using GDP and Affordability Indices. Boston University Undergraduate Economics Association. http://buuea.com/looking-into-the-china-housing-market-bubble-using-gdp-and-affordability-indices/

[27] Huang, Y. (2013) Lack of Affordable Housing Threatens China’s Urban Dream. China Dialogue. https://www.chinadialogue.net/article/show/single/en/6365-Lack-of-affordable-housing-threatens-China-s-urban-dream

[28] Lianjia (n.d.) Houses in Beijing. http://bj.lianjia.com/ershoufang/?utm_source=baidu\&utm_medium=ppc\&utm_term=C309138\&utm_content=D2185\& utm_campaign=J1\&utm_creative=997472706\&utm_network=1\&utm_keyword=4176812494\&utm_placement

[29] Washington DC Real Estate (n.d.). http://www.zillow.com/homes/for_sale/Washington-DC/pmf,pf_pt/41568_rid/4-_beds/3-_baths/80000-100000_price/2 93-366_mp/39.026118,-76.737958,38.87473,-77.073041_rect/11_zm/

[30] Statista (n.d.) Real Gross Domestic Product (GDP) of the District of Columbia from 1997 to 2014. http://www.statista.com/statistics/187846/gdp-of-the-district-of-columbia-since-1997/ 


\section{Appendix}

Table A1. Housing prices in Washington and its surrounding states [10]-[13].

\begin{tabular}{|c|c|c|c|c|c|c|c|c|}
\hline & & 2008 & 2009 & 2010 & 2011 & 2012 & 2013 & 2014 \\
\hline & Jan. & & 302 & 309 & 311 & 360 & 413 & 434 \\
\hline & Apr. & & 322 & 358 & 345 & 406 & 443 & 466 \\
\hline \multirow[t]{5}{*}{ Washington } & Jul. & & 318 & 346 & 354 & 419 & 448 & 460 \\
\hline & Oct. & & 328 & 328 & 368 & 419 & 449 & 449 \\
\hline & Mean & 305.33 & 317.5 & 335.25 & 344.5 & 401 & 438.25 & 452.25 \\
\hline & Jan. & & 137 & 131 & 124 & 127 & 127 & 132 \\
\hline & Apr. & & 136 & 132 & 124 & 131 & 133 & 138 \\
\hline \multirow[t]{5}{*}{ Virginia } & Jul. & & 135 & 130 & 124 & 129 & 134 & 141 \\
\hline & Oct. & & 133 & 128 & 130 & 129 & 134 & 140 \\
\hline & Mean & 139.33 & 135.25 & 130.25 & 125.5 & 129 & 132 & 137.75 \\
\hline & Jan. & & 173 & 159 & 146 & 149 & 149 & 154 \\
\hline & Apr. & & 173 & 159 & 145 & 153 & 158 & 162 \\
\hline \multirow[t]{5}{*}{ Maryland } & Jul. & & 168 & 156 & 147 & 154 & 161 & 164 \\
\hline & Oct. & & 164 & 151 & 154 & 153 & 160 & 161 \\
\hline & Mean & 177.33 & 169.5 & 156.25 & 148 & 152.25 & 157 & 160.25 \\
\hline & Jan. & & 91 & 89 & 85 & 86 & 85 & 86 \\
\hline & Apr. & & 91 & 88 & 86 & 86 & 88 & 89 \\
\hline \multirow[t]{3}{*}{ West Virginia } & Jul. & & 91 & 89 & 86 & 86 & 88 & 90 \\
\hline & Oct. & & 89 & 88 & 86 & 85 & 86 & 89 \\
\hline & Mean & 93.33 & 90.5 & 88.5 & 85.75 & 85.75 & 86.75 & 88.5 \\
\hline \multicolumn{2}{|c|}{ Average housing prices } & 178.83 & 178.19 & 177.56 & 175.94 & 192 & 203.5 & 209.69 \\
\hline
\end{tabular}

Table A2. Housing prices in Washington (and its surrounding places) and Beijing [5].

\begin{tabular}{|c|c|c|c|c|}
\hline Year & Washington Housing Prices (\$/sqft) & Growth Rate & Beijing Housing Prices (\$/sqft) & Growth Rate \\
\hline 2005 & & & 70.938 & \\
\hline 2006 & & & 87.748 & $23.70 \%$ \\
\hline 2007 & & & 135.594 & $54.53 \%$ \\
\hline 2008 & 178.83 & & 158.332 & $16.77 \%$ \\
\hline 2009 & 178.1875 & $-0.36 \%$ & 179.922 & $13.62 \%$ \\
\hline 2010 & 177.5625 & $-0.35 \%$ & 240.594 & $33.74 \%$ \\
\hline 2011 & 175.9375 & $-0.92 \%$ & 228.803 & $-4.90 \%$ \\
\hline 2012 & 192 & $9.13 \%$ & 244.67 & $6.95 \%$ \\
\hline 2013 & 203.5 & $5.99 \%$ & 272.055 & $11.20 \%$ \\
\hline 2014 & 209.6875 & $3.04 \%$ & 280.865 & $3.23 \%$ \\
\hline
\end{tabular}


Table A3. Per Capita income in Washington and Beijing [5] [14].

\begin{tabular}{lll}
\hline Year & Per Capita Income in Beijing (\$) & Per Capita Income in Washington (\$) \\
\hline 2000 & 1250.36 & 32,865 \\
2001 & 1398.81 & 33,225 \\
2002 & 1505.81 & 33,548 \\
2003 & 1677.21 & 34,609 \\
2004 & 1889.42 & 36,689 \\
2005 & 2187.43 & 37,638 \\
2006 & 2558.36 & 40,127 \\
2007 & 3010.25 & 42,829 \\
2008 & 3617.61 & 44,143 \\
2009 & 3915.89 & 42,137 \\
2010 & 4389.89 & 42,547 \\
2011 & 5221.95 & 44,565 \\
2012 & 5802.05 & 47,055 \\
2013 & 6613.36 & 47,717 \\
2014 & 7176.01 & 49,583 \\
\hline
\end{tabular}

Table A4. Urbanization percentage in Beijing from 2000 to 2014 [5].

\begin{tabular}{lll}
\hline Year & Urbanization Percentage \% \\
\hline 2000 & 36.22 \\
2001 & 37.66 \\
2003 & 39.09 \\
2004 & 40.53 \\
2005 & 41.76 \\
2006 & 42.99 \\
2007 & 43.9 \\
2008 & 44.94 \\
2009 & 45.68 \\
2010 & 46.59 \\
2011 & 47.5 \\
2012 & 51.27 \\
2013 & 52.57 \\
2014 & 53.7 \\
\hline
\end{tabular}


Table A5. GDP in washington and Beijing from 2005 to 2014 [5] [30].

\begin{tabular}{ccc}
\hline Year & GDP (billion dollars) in Washington & GDP (billion dollars) in Beijing \\
\hline 2005 & 92.99 & 86.362 \\
2006 & 94.94 & 103.958 \\
2007 & 97.35 & 134.803 \\
2008 & 100.56 & 162.628 \\
2009 & 99.26 & 177.983 \\
2010 & 102.02 & 213.109 \\
2011 & 104 & 257.93 \\
2012 & 104.04 & 284.455 \\
2013 & 103.41 & 324.768 \\
2014 & 105.02 & 348.599 \\
\hline
\end{tabular}

Table A6. Housing market investment in china and U.S. [5] [26].

\begin{tabular}{ccc}
\hline Year & Housing Market Growth in China (\%) & Housing Market Growth in U.S. (\%) \\
\hline 2000 & 8.4 & 5.11 \\
2001 & 9.8 & 5.69 \\
2002 & 12.8 & 8.69 \\
2003 & 14.7 & 14.22 \\
2004 & 24.8 & 17.71 \\
2005 & 14.6 & 14.19 \\
2006 & 25.3 & -2.18 \\
2007 & 29.3 & -17.76 \\
2008 & 23.5 & -25.09 \\
2009 & 17.9 & -23.98 \\
2010 & 32.5 & -2.83 \\
2011 & 27.9 & 1.22 \\
2012 & 16.3 & 14.59 \\
2013 & 19.8 & 17.54 \\
\hline
\end{tabular}

Table A7. Housing price to income ratio [26].

\begin{tabular}{ccc}
\hline \multicolumn{3}{c}{ Housing Price to Income Ratio } \\
\hline Year & Housing Price to Income Ratio in China & Housing Price to Income Ratio in U.S. \\
\hline 2000 & 6.81 & 2.53 \\
2001 & 6.58 & 2.76 \\
2002 & 6.66 & 3 \\
2003 & 6.6 & 3.26 \\
2004 & 7.37 & 3.57 \\
2005 & 7.88 & 3.97 \\
2006 & 7.76 & 3.98 \\
2007 & 7.88 & 3.88 \\
2008 & 6.81 & 3.64 \\
2009 & 8.53 & 3.19 \\
2010 & 8.32 & 3.28 \\
2011 & 8.03 & 3.2 \\
2012 & 7.76 & 3.42 \\
\hline
\end{tabular}

